\title{
ANALISIS KADAR KALIUM (K) DAN POSFORUS (P) PADA LIMBAH KANGKUNG DARAT (Ipomea reptans Poir)
}

\author{
Analysis of Potassium (K) and Phosphorus (P) in Swamp Cabbage Waste (Ipomea reptans Poir)
}

\author{
* Rahmadiana Setianingsih, Siti Nuryanti dan Ratman \\ Pendidikan Kimia/FKIP - Universitas Tadulako, Palu - Indonesia 94118 \\ Received 13 December 2017, Revised 15 January 2018, Accepted 14 February 2018
}

\begin{abstract}
This research is aimed to determine potassium $(K)$ and phosphorus $(P)$ levels in the waste of swamp cabbage. The Spectrodirect instrument was used to analyze the levels of potassium $(K)$ and phosphorus $(P)$ in the waste of swamp cabbage. Based on analysis of the levels of potassium $(K)$ and phosphorus $(P)$ in the waste of swam cabbage, it was obtained that the average value of $K$ concentration in the sample was $5.51213 \mathrm{mg} / \mathrm{kg}$. On the other hand, the average value of $P$ concentration in the sample was $43.19503 \mathrm{mg} / \mathrm{kg}$. From the result of this analysis, it also demonstrated that the concentration of phosphorus $(P)$ was higher than the concentration of potassium (K).
\end{abstract}

Keywords: Potassium (K), phosphorus (P), waste of swamp cabbage

\section{Pendahuluan}

Seiring dengan meningkatnya jumlah penduduk di Kota Palu, maka kebutuhan sayur untuk memenuhi permintaan pasar juga meningkat. Sayuran merupakan bahan makanan yang diperlukan dan memenuhi kebutuhan gizi keluarga. Walaupun kebutuhan untuk mengkonsumsi sayuran tidak terlalu banyak tetapi sangat dibutuhkan baik sebagai sumber mineral. Sayuran dapat tumbuh di dataran rendah maupun dataran tinggi, diantaranya sayuran kangkung. Sayur kangkung ini banyak dikonsumsi masyarakat Kota Palu dan banyak dijumpai di pasar rakyat maupun di swalayan (Hidayati, 2011).

Kangkung adalah sayuran yang cukup terkenal karena murah dan mudah didapatkan di pasaran. Selain itu kangkung yang tumbuh di daerah Palu antara lain kangkung darat dan kangkung air. Kegunaan sayuran selain sebagai sumber vitamin A, mineral dan gizi lainnya yang berguna bagi kesehatan tubuh, juga dapat berfungsi untuk menenangkan syaraf. Kangkung juga memiliki kandungan gizi yang cukup tinggi, selain mengandung vitamin $A, B_{1}$, dan $C$ juga mengandung protein, kalsium, posforus, besi, kalium, karoten dan sitosterol (Margono, 2009).

Daerah Sulawesi Tengah khususnya wilayah Kota Palu banyak terdapat limbah kangkung yang tidak termanfaatkan, hal ini terlihat bahwa limbah kangkung tersebut hanya dibiarkan berserakan disekitar area pasar dan sampah rumah tangga. Limbah kangkung yang tidak termanfaatkan antara lain yaitu pada bagian bawah dari kangkung

*Correspondence

Rahmadiana Setianingsih

Program Studi Pendidikan Kimia, Fakultas Keguruan dan Ilmu Pendidikan, Universitas Tadulako

e-mail: anhachemistry@gmail.com

Published by Universitas Tadulako 2018 (batang, daun, serta akar) dan kangkung yang tidak layak dikonsumsi sehingga tidak terjual oleh pedagang, akhirnya menjadi limbah yang dapat mencemari lingkungan karena limbah tersebut hanya ditumpuk dan dibiarkan membusuk tanpa adanya pengolahan dari limbah kangkung tersebut. Kondisi seperti itu berdampak negatif terhadap lingkungan sehingga perlu dilakukan penanggulangan dari limbah tersebut.

Menurut Suprihatin (2011) bahwa dalam proses pertumbuhannya ada tiga unsur hara yang paling penting serta dibutuhkan oleh tumbuhan yaitu $\mathrm{Ca}, \mathrm{P}$ serta K. Apabila dihubungkan dari yang dikemukakan oleh Focher dkk (1992) dan unsur hara yang paling penting dibutuhkan oleh tumbuhan (Suprihatin, 2011).

Kalium bukan merupakan unsur penyusun jaringan tanaman, namun berperan dalam pembentukan pati, mengaktifkan enzim, pembukaan stomata (mengatur pernapasan dan penguapan), proses fisiologis dalam tanaman, proses metabolik dalam sel, mempengaruhi penyerapan unsur-unsur lain, mempertinggi daya tahan terhadap kekeringan, penyakit selain itu juga berperan dalam perkembangan akar (Pratiwa, 2014). Sedangkan posforus (P) bertugas mengedarkan energi keseluruh bagian tanaman, berguna untuk merangsang pertumbuhan dan perkembangan akar, khususnya akar benih dan tanaman muda. Selain itu, posforus juga berfungsi sebagai bahan mentah untuk pembentukan sejumlah protein tertentu, membantu asimilasi dan pernapasan, mempercepat pembungaan dan pembuahan, serta mempercepat pemasakan biji dan buah (Suprihatin, 2011).

Sujatmiko (2010) melakukan penelitian tentang analisis kadar posforus dan besi dalam sawi hijau (Brassica juncea L.) secara spektrometri sinar tampak. Dari analisis data diperoleh kadar posforus pada sawi hijau didestruksi dengan $\mathrm{H}_{2} \mathrm{SO}_{4}$ pekat adalah $0.5621 \pm 0.9073 \% \mathrm{~b} / \mathrm{b}$ dan dengan $\mathrm{HNO}_{3}$ 
pekat adalah $0.8558 \pm 0.1884 \%$ b/b. Kadar besi pada sawi hijau yang didestruksi dengan $\mathrm{H}_{2} \mathrm{SO}_{4}$ pekat adalah $0.11318 \pm 0.0508 \% \mathrm{~b} / \mathrm{b}$ dan dengan $\mathrm{HNO}_{3}$ pekat adalah $0.13548 \pm 0.0524 \% \mathrm{~b} / \mathrm{b}$. Pada uji ANAVA-A menunjukkan adanya perbedan yang signifikan antara kadar posforus dan kadar besi pada sawi hijau yang didestruksi dengan asam pekat.

Hidayati (2011) melakukan penelitian tentang kadar kalsium (Ca) dan kalium (K) pada sayur kangkung (Ipomea reptans) yang tumbuh di Kota Palu. Hasil penelitian menunjukkan bahwa kadar air dalam sampel diperoleh $82.41 \%$ dan kadar abu diperoleh $18.07 \%$. Kandugan rata-rata kalsium dan kalium masing-masing berturut-turut 56.24 $\mathrm{mg} / 100 \mathrm{~g}$ dan $419.8 \mathrm{mg} / 100 \mathrm{~g}$.

Fitriani, dkk (2012) melakukan penelitian terkait logam kalium (K) dan kalsium (Ca) pada buah labu siam (Sechium edule) yang tumbuh di daerah Palolo dan Kebun kopi serta kaitannya dengan tempat tumbuhnya (tanah). Penelitian ini menggunakan spektrofotometri serapan atom (SSA). Hasil penelitiannya menunjukkan bahwa labu siam di Palolo memiliki kadar kalium (K) sebesar $134.35 \mathrm{mg} / 100 \mathrm{~g}$ dan kadar kalsium $(\mathrm{Ca})$ sebesar $38.53 \mathrm{mg} / 100 \mathrm{~g}$, sedangkan labu siam di Kebun Kopi memiliki kadar Kalium (K) sebesar $177.42 \mathrm{mg} / 100 \mathrm{~g}$ dan kadar kalsium (Ca) sebesar $20.535 \mathrm{mg} / 100 \mathrm{~g}$. Hasil penelitian tersebut menunjukkan bahwa tempat tumbuh tanaman mempengaruhi kandungan unsur hara yang dimiliki tanaman buah labu siam.

Tulisan ini bertujuan mendeskripsikan penelitian tentang analisis kadar kalium $(\mathrm{K})$ dan posforus (P) pada limbah kangkung darat (Ipomea Reptans Poir).

\section{Metode}

\section{Alat dan Bahan}

Alat yang telah digunakan pada penelitian ini adalah, neraca digital ARC-120, labu ukur, gelas kimia, gelas kimia, cawan porsalin, batang pengaduk, pipet tetes, oven MMM Medcenter, gegep, spektrofotometer SpectroDirect RS232 serial No: 1257060900344, tanur FB1410M, desikator, kertas saring, corong pisah, botol semprot dan stopwatch.

Bahan yang telah digunakan pada penelitian ini adalah sampel limbah kangkung darat, larutan $\mathrm{HNO}_{3}$ Pekat (KC-aA), aquades, pereaksi kalium (K) yaitu potassium T (TIT-519670) dan pereaksi posforus (P) yaitu tablet phospate 1 (TIT513040), tablet phospate 2 (TIT-513050 BT)

\section{Prosedur Penelitian}

\section{Penentuan kadar air}

Limbah kangkung dipotong-potong \pm 1 $\mathrm{cm}$, selanjutnya dikeringkan tanpa matahari dan diangin-anginkan pada suhu kamar, kemudian dimasukkan ke dalam cawan penguap dan ditimbang 100 gram, kemudian dipanaskan ke dalam oven pada suhu $100{ }^{\circ} \mathrm{C}$ selama \pm 3 jam. Setelah itu didinginkan ke dalam desikator dan ditimbang. Kemudian ditentukan kadar airnya dengan rumus sebagai berikut (Sudarmadji, dkk., 1989):

Kadar air $=\frac{\text { berat kangkung awal }- \text { berat kangkung akhir }}{\text { berat kangkung awal }} \times 100 \%$

\section{Penentuan kadar abu}

Sampel kangkung kering ditimbang, kemudian sampel kangkung kering diabukan dalam tanur pada suhu $700{ }^{\circ} \mathrm{C}$ selama \pm 3 jam. Kemudian abu yang diperoleh ditimbang dan ditentukan kadar abunya dengan rumus sebagai berikut (Sudarmadji, dkk., 1989):

$$
\text { Kadar abu }=\frac{\text { Berat } a b u}{\text { Berat awal }} \times 100 \%
$$

\section{Penyiapan sampel}

1,74 gram sampel kangkung ditimbang kemudian menambahkan larutan $\mathrm{HNO}_{3}$ pekat sebanyak $10 \mathrm{~mL}$ pada masing-masing sampel bertujuan untuk mengoksidasi senyawa-senyawa organik yang terdapat pada sampel. Selain itu agar senyawa-senyawa lain yang masih terdapat dalam sampel terurai, kemudian disaring sampai terpisah antara filtrat dan residu. Selanjutnya filtrat yang diperoleh kemudian diencerkan dengan aquades dalam labu ukur $100 \mathrm{~mL}$ sampai tanda batas.

\section{Analisis kadar K dan P SpektroDirect}

\section{Analisis kadar kalium}

Larutan yang sudah siap untuk dianalisis dimasukkan ke dalam vial. Analisis kadar K dilakukan dengan cara memasukkan masingmasing $10 \mathrm{~mL}$ sampel ke dalam 3 buah vial dan menambahkan reagen (pereaksi) $\mathrm{K}$ yaitu Potassium $\mathrm{T}$ ke dalam masing-masing vial tersebut, kemudian dikocok sampai pereaksi larut semua menjadi homogen.

\section{Analisis kadar posforus}

Menganalisis kadar P pada sampel langkah kerjanya sama dengan menganalisis kadar $\mathrm{K}$ hanya saja untuk menganalisis kadar $\mathrm{P}$ menggunakan reagen (pereaksi) yang berbeda yaitu ditambahkan tablet phosphate 1 dan 2 ke dalam vial masingmasing 1 tablet phosphate 1 dan 1 tablet phosphate 2, kemudian dikocok sampai pereaksi larut semua menjadi homogen.

Dalam penelitian ini masing-masing limbah kangkung darat yang akan dianalisis kadar $\mathrm{K}$ dan kadar P dilakukan pengukuran sebanyak 3 kali. Sampel dianalisis menggunakan SpectroDirect, selanjutnya hasil yang diperoleh dirata-ratakan.

\section{Hasil dan Pembahasan}

\section{Kadar air dan kadar abu pada limbah kangkung darat}

Analisis kadar air bertujuan untuk mengetahui seberapa banyak kadar air yang terdapat dalam limbah kangkung yang akan dianalisis. Ada beberapa metode analisis kadar air pada sampel, 
diantaranya adalah metode pengeringan/oven, metode destilasi dan metode kimiawi. Pada penelitian ini, analisis kadar air menggunakan metode pengeringan menggunakan oven. Penentuan kadar air yang diperoleh dengan cara berat sampel awal (limbah kangkung darat yang dikeringkan pada suhu kamar) dikurangi dengan berat sampel akhir (limbah kangkung darat yang dikeringkan dalam oven $105^{\circ} \mathrm{C} \pm 3$ jam hal ini berfungsi untuk menghilangkan kadar air yang terdapat pada suatu sampel karena air yang terkandung dalam sampel tersebut akan menguap dalam suhu tersebut (Harjadi, 1993) dan membandingkan dengan berat sampel awal kemudian dikalikan 100\%. Metode pengeringan dengan oven didasarkan atas prinsip perhitungan selisih bobot bahan (sampel) sebelum dan sesudah pengeringan. Selisih bobot tersebut merupakan air yang teruapkan dan dihitung sebagai kadar air bahan. air di dalam bahan pangan ada dalam tiga bentuk, yaitu air bebas, air terikat lemah atau air teradsorbsi dan air terikat kuat. Pengukuran kadar air bahan pangan, air yang terukur adalah air bebas dan air teradsorbsi. Jadi, kadar air suatu bahan pangan merupakan gabungan dari air bebas dan air teradsorbsi di dalam bahan tersebut (Legowo, dkk., 2007).

Analisis kadar air dan kadar abu yang diperoleh dalam Tabel 1.

Tabel 1 Data kadar air dan kadar abu dalam Sampel

\begin{tabular}{ccc}
\hline Sampel & Kadar air (\%) & $\begin{array}{c}\text { Kadar abu } \\
(\%)\end{array}$ \\
\hline $\begin{array}{c}\text { Limbah kangkung } \\
\text { darat }\end{array}$ & 83,370 & 10,463 \\
\hline
\end{tabular}

Langkah selanjutnya yaitu penentuan kadar abu pada limbah kangkung darat. Hasil penelitian ini diperoleh kadar air pada limbah kangkung darat yaitu sebesar $10.463 \%$. Menurut Lubis (2014) ada dua prosedur yang umum digunakan untuk mendestruksi bahan-bahan organik dalam sampel, yaitu dengan oksidasi basah (wet oksidation) dan pengabuan kering (dry ashing). Dalam penelitian ini dekstruksi sampel menggunakan prosedur pengabuan kering. Fungsi dari destruksi yaitu untuk memutuskan ikatan antara senyawa organik dengan logam yang akan dianalisis. Penentuan kadar abu suatu sampel padat, dapat melakukan estimasi beberapa unsur-unsur anorganik atau mineral yang terkandung dalam sampel tersebut. Kadar abu dapat ditentukan dengan cara mengabukan sampel yang akan dianalisis akan tetapi sampel tersebut dihilangkan kadar airnya terlebih dahulu kemudian dikeringkan dalam oven pada $105^{\circ} \mathrm{C}$. Sampel tersebut akan diabukan dalam tanur pada suhu $700{ }^{\circ} \mathrm{C}$, kemudian menimbang sampel tersebut. Kadar abu diperoleh dengan cara membandingkan berat abu dengan berat kering kemudian dikalikan $100 \%$.

Pengukuran konsentrasi logam dapat dilakukan dengan menggunakan alat SpectroDirect. Jika menggunakan alat Spectro direct cuplikan suatu sampel yang akan diukur haruslah berupa larutan yang berwarna. Oleh karena itu, untuk sampel yang tidak memiliki warna harus terlebih dulu dibuat berwarna dengan menggunakan reagent spesifik yang akan menghasilkan senyawa berwarna, sehingga dalam penelitian ini sampel abu yang diperoleh dari proses pengabuan dilarutkan dengan $\mathrm{HNO}_{3}$ pekat dan dikomplekskan dengan reagen (pereaksi), $\mathrm{HNO}_{3}$ berfungsi sebagai mengoksidasi senyawa-senyawa organik yang terdapat dalam sampel.

\section{Analisis kadar $k$ dalam sampel}

Analisis kadar K yang diperoleh dalam Tabel 2.

Tabel 2 Data Kadar K dalam Sampel

\begin{tabular}{llll}
\hline Sampel & Perlakuan & $\begin{array}{l}\text { Konsentrasi } \\
\text { pada Sampel } \\
(\mathrm{mg} / \mathrm{L})\end{array}$ & $\begin{array}{l}\text { Konsentrasi } \\
\text { Berat Kering } \\
(\mathrm{mg} / \mathrm{Kg})\end{array}$ \\
\hline Limbah & I & 9,6 & 5,7727 \\
Kangkung & II & 9,4 & 5,65244 \\
Darat & III & 8,5 & 5,11124 \\
\hline Rata-rata & & 9,1670 & 5,5121 \\
\hline
\end{tabular}

\section{Analisis kadar p dalam sampel}

Analisi kadar P yang diperoleh dalam Tabel 3.

Tabel 3 Data Kadar P dalam Sampel

\begin{tabular}{llll}
\hline Sampel & Perlakuan & $\begin{array}{l}\text { Konsentrasi } \\
\text { pada Sampel } \\
(\mathrm{mg} / \mathrm{L})\end{array}$ & $\begin{array}{l}\text { Konsentrasi } \\
\text { Berat Kering } \\
(\mathrm{mg} / \mathrm{Kg})\end{array}$ \\
\hline Limbah & I & 73,5 & 44,19723 \\
Kangkung & II & 71 & 42,69393 \\
Darat & III & 71 & 42,69393 \\
\hline Rata-rata & & 71.8330 & 43,1950 \\
\hline
\end{tabular}

Analisis kadar K dikomplekskan dengan reagen Potassium T. Hasil yang diperoleh pada penelitian ini adalah konsentrasi $\mathrm{K}$ dalam sampel limbah kangkung darat dengan nilai rata-rata yaitu 9,1670 $\mathrm{mg} / \mathrm{L}$ dengan konsentrasi berat kering sampel diperoleh nilai rata-rata yaitu $5,5121 \mathrm{mg} / \mathrm{kg}$. Analisis kadar P dikomplekskan dengan tablet phosphate 1 dan phosphate 2 . Hasil yang diperoleh pada penelitian ini adalah dengan nilai rata-rata yaitu $71,8330 \mathrm{mg} / \mathrm{L}$ sedangkan konsetrasi berat kering yang diperoleh dengan nilai rata-rata yaitu $43,1950 \mathrm{mg} / \mathrm{kg}$. Jika dibandingkan hasil yang terdapat pada literatur dan hasil dari penelitian ini memiliki perbedaan yang cukup jauh untuk hasil analisis konsentrasi kalium dan posforus dalam sampel. Jika dibandingkan dengan hasil penelitian dan literatur yang ada, keduanya sangatlah berbeda hal ini mungkin disebabkan karena pada literatur kadar $\mathrm{K}$ dan $\mathrm{P}$ digunakan kangkung darat yang segar dan diambil secara keseluruhan bagian pucuk, batang serta daun yang lebih banyak, sedangkan pada penelitian kadar $\mathrm{K}$ dan $\mathrm{P}$ hanya menggunakan limbahnya yaitu pada bagian bawah dari kangkung darat tersebut yang tidak digunakan serta kangkung darat yang sudah tidak layak 
dikonsumsi lagi. Sehingga kadar $\mathrm{K}$ dan $\mathrm{P}$ yang diperoleh juga berbeda.

Menurut Rocha, dkk., (2014) kalium dan posforus berhubungan erat dengan pengembangan kerangka dan pemeliharaan dan mineralisasi tulang. Mineral utama yang diperlukan adalah kalium dan posforus. Kalium dapat dijumpai pada air-air berkesadahan tinggi sedangkan posforus dapat dijumpai pada tanaman air. Di dalam ekosistem air terjadi daur posforus. Posfat yang terlarut di dalam air diserap oleh ganggang dan tumbuhan air (Ye, dkk., 2006). Penelitian lain yang dilakukan oleh Adebayo, dkk (2013) K kompleks dengan P dalam hidroksiapatit untuk membentuk kepala, ekor, bahan kristal tulang dan berpartisipasi dalam beberapa proses fisiologi.

Dari hasil analisis yang menunjukkan bahwa dalam limbah kangkung darat terdapat $\mathrm{K}$ dan $\mathrm{P}$ maka dapat disimpulkan bahwa secara ilmiah limbah Kangkung darat bisa digunakan sebagai bahan dasar pembuatan pupuk organik. Hal ini sejalan dengan aturan Food and Agriculture Organization (FAO) yang telah menetapkan kriteria dasar untuk pupuk, yakni kandungan unsur makro harus mempunyai nilai minimal $\mathrm{N}$ (12\%), P (8\%), dan K (6\%) disamping kandungan unsur mikro seperti $\mathrm{Ca}, \mathrm{Fe}, \mathrm{Mg}, \mathrm{Cu}, \mathrm{Zn}, \mathrm{Mn}$, dan sebagainya (Lestari dkk, 2011).

\section{Kesimpulan}

Hasil penelitian yang dilakukan maka disimpulkan bahwa diperoleh nilai rata-rata konsnetrasi berat kering pada Kalium dalam sampel limbah kangkung darat yaitu 5,5121 $\mathrm{mg} / \mathrm{kg}$. Nilai rata-rata konsentrasi berat kering Posforus dalam sampel limbah kangkung darat yaitu $43,1950 \mathrm{mg} / \mathrm{kg}$.

\section{Ucapan Terima Kasih}

Ucapan terima kasih penulis berikan kepada laboran laboratorium Pendidikan Kimia Fakultas Keguruan dan Ilmu Pendidikan Universitas Tadulako dan semua pihak yang banyak membantu penulis dalam menyelesaikan penelitian ini.

\section{Referensi}

Adebayo, I. A. \& Omitoyin, B. O. (2013). Essentiality of calcium supplement in the diets of heterobranchus bidorsalis fingerlings. International Journal of Fisheries and Aquaculture, 5(5), 98-103.

Fitriani, N. C., Walanda, D. K., Rahman, N. (2012). Penentuan kadar kalium (K) dan kalsium (Ca) dalam labu siam (sechium edule) serta pengaruh tempat tumbuhnya. Jurnal Akademika Kimia, 1(4), 174-180.

Focher, B., Naggi, A., Tarri, G., Cosami, A. \& Terbojevich, M. (1992). Structural differences between chitin polymorphs and their precipitates from solution - evidence from CPMAS ${ }^{13}$ C-NMR, FT-IR and FT-Raman spectroscopy. Carbohydrate Polymers, 17(2), 97-102.

Harjadi, W. (1993). Ilmu kimia analitik dasar. Jakarta: Gramedia.

Hidayati, S. N. (2011). Kadar kalsium (Ca) dan kalium pada sayur kangkung (Ipomea reptans) yang tumbuh di kota Palu. Skripsi FKIP UNTAD Palu. Tidak diterbitkan.

Legowo A. M., Nurwantoro, \& Sutaryo (2007). Buku ajar analisis pangan. Semarang: UNDIP Press.

Lestari, I. P., Sastro, Y. \& Irawati, A. F. C. (2011). Kajian teknologi fermentasi limbah ikan sebagai pupuk organik. Jakarta: Balai Pengkajian Teknologi Pertanian.

Lubis, D. A. (2014). Akumulasi logam timbal (Pb) dan tembaga (Cu) pada ikan kuniran (upeneus sulphureus) dari perairan estuaria teluk Palu Sulawesi Tengah. Skripsi Sarjana pada Fakultas Keguruan dan Ilmu Pendidikan. Universitas Tadulako. Palu: tidak diterbitkan.

Margono, (2009). Analisis kadar kalsium dan besi pada kangkung (ipomea reptans) menggunakan dekstruksi asam pekat. Skripsi Sarjana. Yogyakarta: Fakultas Sains dan Teknologi. Tidak diterbitkan.

Pratiwa \& Riyadi, (2014). Peran unsur hara kalium bagi tanaman. [online].http://www.bbpplembang.info/index.php/arsip/artikel/artikelpertanian/833-peran-unsur-hara-kalium-kbagi-tanaman. Diunduh 3 Mei 2015.

Rocha, C. B., Portelinha, M. K., Fernandes, J. M., Britto, A. C. P., Piedras, S. R. N. \& Pouey, J. L. O. F. (2014). Dietary phosphorus requirement of pejerrey fingerlings (odontesthes bonariensis). Revista Brasileira de Zootecnia, 43(2), 55-59.

Sudarmadji, Haryono \& Suhardi, B. (1989). Analisa bahan makanan dan pertanian. Yogyakarta: Liberty Yogyakarta.

Sujatmiko, (2010). Analisis kadar fosfor dan besi dalam sawi hijau (Brasicca juncea. L) secara spektrometri sinar tampak. Skripsi Sarjana. Yogyakarta: Fakultas Sains dan Teknologi. Tidak diterbitkan.

Suprihatin. (2011). Proses pembuatan pupuk cair dari batang pohon pisang. Jurnal Teknik Kimia, 5(2), 429-433.

Ye, C. X., Liu, Y. J., Tian, L. X., Mai, K. S., Du, Z. Y., Yang, H. J. \& Niu, J. (2006). Effect of dietary calcium and phosphorus on growth, feed efficiency, mineral content and body composition of juvenil grouper, Epinephelus coioides. Aquaculture, 255, 263-271. 